\title{
Effects of soy protein isolates on quality of chocolates during storage
}

\begin{abstract}
The effect of soy protein isolate (SPI) on oxidation rate, changes in color and hardness, and microbiological aspect of chocolates during storage were studied. The Peroxide Value (PV) of the control and 5\% showed SPI were highest in week 3 and decreased at the following week, while $10 \%$ SPI showed the lowest PV in week 10 as compared to the others. The Anisidine Value (AV) of all chocolates showed an increasing pattern during 10 weeks of storage. The Total Oxidation Value (TV) of all chocolates was found to be highest at week 3 and lowest at week 10 when $10 \%$ SPI was used. During storage, all chocolates slightly increased in hardness and turned darker in color. The Total Plate Count (TPC) of the control and SPI chocolates was less than 1,000 colonies/g.
\end{abstract}

Keyword: Soy protein isolate; Chocolates; Storage; Quality 